\title{
INNOWACYJNOŚĆ W GOSPODARSTWACH AGROTURYSTYCZNYCH
}

\begin{abstract}
Zarys treści: Przestrzeń agroturystyczną w Polsce południowo-wschodniej determinuje wiele czynników o różnym charakterze. Aktualnie coraz większą rolę przypisuje się innowacjom. Są one wskazane dla osiągnięcia konkurencyjności ofert turystycznych na tych obszarach. W pracy dokonano identyfikacji innowacji wprowadzanych przez gospodarstwa agroturystyczne zlokalizowane w czterech województwach wskazanej części kraju: lubelskim, małopolskim, podkarpackim i świętokrzyskim. Głównym celem jest ocena innowacyjności określonych przedsiębiorstw. W analizie uwzględniono opinie na ten temat w ramach wybranej grupy 607 posiadaczy gospodarstw agroturystycznych. Badania ankietowe wykonano w 2016 roku.
\end{abstract}

Słowa kluczowe: obszary wiejskie, innowacje, innowacyjność, agroturystyka, gospodarstwo agroturystyczne.

\section{Wprowadzenie}

W obecnych czasach innowacyjność traktowana jest jako istotny czynnik osiągania przewagi rynkowej. Jest ona rozumiana jako możliwość tworzenia i wdrażania zmian w różnych sferach życia społeczno-gospodarczego (Janasz 2004). Innowacyjność umożliwia generowanie przewagi przedsiębiorstw na rynku w dobie wysokiej konkurencyjności (Janasz 2005; Alejziak 2009). Inaczej postrzega innowacyjność P.F. Drucker (1992), określając ją jako zmiany - obejmujące wszystkie sfery działalności przedsiębiorstwa - rodzajów produktów i usług w ofercie, metod marketingu, organizacji i zarządzania lub cen zbytu. Może być to także chęć wspierania kreatywności we wprowadzaniu produktów bądź usług, czy nowatorstwo technologiczne oraz rozwój nowych procesów (Alejziak 2009) (za: Lumpkin, Dess 2001).

Termin innowacja pochodzi od łacińskiego słowa innovatio, co znaczy wprowadzenie nowego elementu. Problematykę innowacji w ujęciu naukowym poruszył po raz pierwszy J. Schumpeter (1939), przenosząc pojęcie na grunt ekonomii. 
Określił on, że innowacja oznacza proces zastosowania kombinacji w zakresie nowego produktu, alternatywnej metody produkcji, stworzenia dodatkowego rynku zbytu, pozyskania innego surowca lub półfabrykatu (Schumpeter 1960). Z kolei według opinii P. Niedzielskiego i in. (2007), innowacja stanowi zorganizowane działanie przedsiębiorców szukających praktycznego wykorzystania nowych sposobów w celu uzyskania określonych efektów ekonomicznych, efektywniejszego zaspokajania potrzeb konsumentów oraz lepszego spożytkowania zasobów.

W literaturze, oprócz wyżej wymienionych, istnieje wiele różnorodnych podejść do problematyki innowacyjności oraz innowacji, które ulegały nieustannej ewolucji. Pomimo różnic, większość zajmujących się tym zagadnieniem uznaje, że przy ich wdrażaniu najbardziej istotne są efekty (Szymańska 2013).

Dotychczas odnoszono się do zagadnienia innowacyjności względem pozarolniczych podmiotów gospodarczych (Niedzielski i in. 2007; Wyszkowska 2012). Niemniej współcześnie wprowadzanie innowacji w gospodarstwach rolnych jest wymogiem rynkowym. Przy tym poszerzanie wiedzy na temat innowacji w rolnictwie zachodzi z dużo słabszą dynamiką niż odnośnie innych działów gospodarki (Pałka 2015). Dlatego rozwijanie problematyki w zakresie innowacyjności w gospodarstwach agroturystycznych może wypełnić istniejącą lukę badawczą.

W związku z tym, celem pracy jest określenie stopnia innowacyjności gospodarstw agroturystycznych. Studium przypadku stanowiły gospodarstwa zlokalizowane w Polsce południowo-wschodniej. Podstawą statystyczną badań były dane pierwotne, czyli wyniki bezpośrednich badań ankietowych przeprowadzonych w 2016 roku w 607 przedsiębiorstwach agroturystycznych występujących w województwach: świętokrzyskim (30\% podmiotów), lubelskim (27\%), podkarpackim (24\%) i małopolskim (20\%). Zakres przestrzenny, jak również próba badawcza zostały dobrane w sposób celowy. Obiekty agroturystyczne musiały mieć zarejestrowaną działalność w urzędzie gminy oraz istnieć na rynku turystycznym od pięciu lat.

W ocenie autorów południowo-wschodnia część kraju stanowi modelowy obszar badań w zakresie podjętej tematyki. Jest to region bogaty w tereny cenne pod względem przyrodniczym, co sprzyja rozwojowi działalności agroturystycznej. Walory przyrodnicze i krajobrazowe tworzą m.in.: pagórkowato-górzyste ukształtowanie terenu, rozległe kompleksy leśne czy atrakcyjne szlaki turystyczne. Agroturystyka na tym obszarze stanowi priorytetową działalność usługową, która pozostaje w centrum zainteresowania władz samorządowych, począwszy od gminnych po wojewódzkie. Baza materialna i niematerialna w turystyce wspierana jest poprzez dotacje lub subwencje pochodzące z różnych źródeł. Przeznacza się je m.in. na realizację programów inwestycyjnych promujących innowacyjność.

Dla potrzeb opracowania za innowacje w agroturystyce uznano wszystkie zmiany przeprowadzone w agroturystycznych gospodarstwach, które spowodowały zastąpienie do tej pory używanych rozwiązań nowymi dla danego obiektu. 
Minimalnym wymogiem zaliczenia konkretnego rozwiązania do innowacji jest w tym przypadku stanowienie nowości dla wprowadzającego ją podmiotu. Dlatego innowacjami w agroturystyce są zmiany usprawniające, a także te o charakterze przełomowym.

Z kolei w przypadku innowacyjności przyjęto za K.B. Matusiakiem (2011), że jest ona cechą podmiotów, oznaczającą zdolność do tworzenia lub pozyskiwania nowych bądź ulepszonych produktów, procesów, rynków oraz metod organizacji. Ta cecha związana jest $\mathrm{z}$ aktywnym angażowaniem się $\mathrm{w}$ procesy innowacyjne i podejmowanie działań w tym kierunku. Oznacza także zaangażowanie w zdobywanie zasobów i umiejętności niezbędnych do uczestniczenia w wymienionych procesach.

Do celów interpretacji rezultatów ankiety użyto metod analizy statystycznej, porównawczej i opisowej.

\section{Rodzaje innowacji w agroturystyce}

Innowacje kojarzy się coraz powszechniej z rynkiem usług turystycznych, gdyż innowacyjność odgrywa znaczącą rolę w osiąganiu przez podmioty turystyczne przewagi konkurencyjnej. Pod wpływem procesów globalizacji przedsiębiorstwa turystyczne podejmują aktywność w tym zakresie, ponieważ determinuje to ich dalszy rozwój (Gancarczyk 2012).

Istniejące w gospodarce rynkowej dążenie do osiągnięcia przewagi konkurencyjnej dokonuje się poprzez zwiększanie efektywności produkcji bądź wdrażanie produktów. W praktyce polega to na wykorzystywaniu wyników projektów badawczych, nowych koncepcji i pomysłów (Janasz 2004). Innowacje w gospodarce opartej na wiedzy stanowią priorytetowy warunek wzrostu konkurencyjności, dlatego niezbędne jest rozwijanie wielu rodzajów innowacji, także w przypadku podmiotów turystycznych (Bednarska i in. 2007; Panasiuk 2014).

Według I. Lichniaka (2010), poziom innowacyjności przedsiębiorstw uzależniony jest od szeregu czynników. Do najważniejszych zalicza się:

- kreatywność,

- właściwą umiejętność wykorzystywania potencjału,

- posiadane kompetencje,

- odpowiedni zbiór informacji o rynku.

Poza czynnikami wspierającymi rozwój innowacyjności występują także bariery go hamujące. Jedną z nich może być brak własnego kapitału, przy dość ograniczonych możliwościach dostępu do innych jego źródeł. Niechęć do innowacji bywa często wywołana brakiem wiedzy na ich temat.

Należy w tym miejscu przypomnieć, że innowacje nie przedstawiają jednorodnego zbioru. Najczęściej dzieli się je na: produktowe, procesowe, marketingowe, organizacyjne (tab. 1). Innowacje produktowe wiążą się z wprowadzeniem na 
rynek nowego produktu lub wyraźnego jego ulepszenia pod kątem wartości. Innowacje procesowe dotyczą implementacji nowych albo ulepszonych metod wytwarzania bądź dystrybucji produktów rynkowych. Innowacje marketingowe z kolei to wdrożone nowatorskie rozwiązania w sferze marketingu. Dotyczą one zwykle czterech aspektów - produktu, marki, polityki cenowej, czynności promocyjnych. Ostatni typ - innowacje organizacyjne definiowane są jako nowe koncepcje organizacji aktywności gospodarczej. W perspektywie ostatnich lat wyróżnia się również innowacje instytucjonalne, które polegają na stosowaniu odpowiednich procedur prawnych, standardów, umożliwiających nawiązywanie współpracy, współdziałanie.

Tabela 1. Rodzaje i cechy innowacji oraz obszary zarządzania nimi

\begin{tabular}{cll}
\hline Innowacje & \multicolumn{1}{c}{ Cechy innowacji } & Obszary zarządzania innowacjami \\
\hline Produktowe & $\begin{array}{l}\text { Wprowadzenie na rynek produk- } \\
\text { tów nowych bądź udoskonalonych }\end{array}$ & $\begin{array}{l}\text { Struktura produkcji uzależniona od } \\
\text { potrzeb nabywców, ochrona przy- } \\
\text { rody, jakość produktów }\end{array}$ \\
\hline Procesowe & $\begin{array}{l}\text { Wdrożenie innych sposobów } \\
\text { produkcji, dystrybucji, dostaw, } \\
\text { sprzedaży itd. }\end{array}$ & $\begin{array}{l}\text { Technologie produkcji, formy } \\
\text { sprzedaży, procesy zaopatrzenia, } \\
\text { źródła finansowania }\end{array}$ \\
\hline Marketingowe & $\begin{array}{l}\text { Zaimplementowanie nowych roz- } \\
\text { wiązań zaspokajających potrzeby } \\
\text { w dążeniu do zysku, dotyczących } \\
\text { np. cen, marki, reklamy }\end{array}$ & $\begin{array}{l}\text { Marketing w zakresie cen, sprze- } \\
\text { daży, kanałów dystrybucji, relacji } \\
\text { z klientami }\end{array}$ \\
\hline Organizacyjne & Nowy model organizacji & $\begin{array}{l}\text { Zasoby pracy, wiedza, doświad- } \\
\text { czenie, powiązania rynkowe }\end{array}$ \\
\hline
\end{tabular}

Źródło: opracowanie własne na podstawie M. Dębniewskiej i K. Wojtowicz (2014).

Analogicznie na rynku usług agroturystycznych innowacyjność ma charakter niejednorodny. W agroturystyce winno się brać pod uwagę przede wszystkim te segmenty rynku, do których produkty turystyczne na wsi się odnoszą. Wynika to ze zróżnicowanych oczekiwań względem innowacyjności w produktach agroturystycznych, które są uzależnione od grup odbiorców. Najbardziej „,proinnowacyjni” są turyści biznesowi, których oczekiwania skierowane są w stronę atrakcyjnych i nowoczesnych usług świadczonych w przestrzeni wiejskiej. Przeciwni innowacyjności są głównie zagraniczni goście i turyści weekendowi. W ich przypadku udoskonalanie produktów agroturystycznych potrafi przeszkodzić w zaspokajaniu zgłaszanych przez nich potrzeb, powodując brak satysfakcji z nabywanych usług (Puciato, Woś 2011).

Niebagatelną kwestią innowacyjności w odniesieniu do agroturystyki jest też jej zakres przedmiotowy. Uzależniony jest on przy tym od możliwości i umiejętności rolnika - właściciela oraz zasobów gospodarstwa. Oczywistym jest fakt, 
że poziom zmian przyjętych w rozpatrywanym sektorze musi zostać zatrzymany w takim miejscu, aby wzrost atrakcyjności produktu nie wywołał zaburzenia jego istoty, czyli rdzenia. Wprowadzenie niektórych innowacji może obniżyć stopień „wiejskości” oferowanych produktów turystycznych, co skutkuje rezygnacją części klientów z usług. Zatracenie wiejskiego charakteru usług stwarza zagrożenie dla utrzymania się gospodarstwa na konkurencyjnym rynku agroturystycznym.

Aktualnie dzięki innowacjom kształtowana jest nowa jakość rynku turystycznego, polegająca m.in. na bardziej wnikliwym sposobie zaspokajania potrzeb konsumentów (Szymańska 2013). Innowacje wpływają więc bezpośrednio na strukturę rynku turystycznego i są motorem jego rozwoju.

\section{Innowacyjność gospodarstw w agroturystyce południowo-wschodniej Polski - wybrane zagadnienia}

Badania terenowe dotyczyły zbiorowości 607 gospodarstw agroturystycznych zlokalizowanych łącznie w 110 gminach (276 miejscowości). Najczęściej wymieniane miejscowości (uszeregowane malejąco: od 2,6\% do 1\% wskazań) to: Polańczyk, Wola Uhruska, Susiec, Porąbka Uszewska, Kąty Podkarpackie, Brzeziny, Okuninka, Jodłówka Tuchowska, Iwkowa, Myczków. Wśród gmin dominowały (od 3,8\% do 2,5\% respondentów): Solina, Tuchów, Andrychów, Dębno, Iwkowa, Susiec, Zwierzyniec, Leżajsk, Kazimierz Dolny i Zagnańsk. Ankietowani reprezentowali przede wszystkim (od 17\% do 3\%) powiaty: kielecki, włodawski, tarnowski, brzeski, leżajski, Puławy, leski, jędrzejowski, chełmski oraz wadowicki.

Biorąc pod uwagę strukturę demograficzną respondentów, najmłodszy z nich miał 20 lat, najstarszy - 79 lat, a średnia wieku stanowiła 48 lat. Kobiety były przeważającą liczebnie grupą (58\%). Z kolei pod względem poziomu wykształcenia $54 \%$ badanych posiadała wykształcenie średnie, 23\% - wyższe, 19\% - zawodowe, zaś $4 \%$ - podstawowe.

Badane gospodarstwa miały zróżnicowaną strukturę wielkościową. Ich areał wynosił od 0,5 do 400 ha (przeciętnie 9,4 ha) - (ryc. 1). Trzon zbiorowości gospodarstw $(50 \%)^{1}$ odznaczył się powierzchnią od 0,5 do 8,6 ha. Przy tym $81 \%$ właścicieli nie zadeklarowało planów powiększania gospodarstwa. Połowa usługodawców oferuje od 8 do 16 miejsc noclegowych, co daje średnią równą 13 miejsc. Najczęściej noclegi udzielane są w obiektach mieszczących od 2 do 5 pokoi. Biorąc pod uwagę czas istnienia na rynku turystycznym warto wspomnieć, że 50\% podmiotów świadczy usługi od 11 do 17 lat. Ważny jest fakt, że wszystkie uwzględnione gospodarstwa prowadziły aktywność produkcyjną (roślinną lub zwierzęcą), co jest zgodne $\mathrm{z}$ istotą gospodarstwa agroturystycznego.

${ }^{1}$ Połowa badanych podmiotów, która uszeregowana rosnąco pod względem analizowanej zmiennej znajduje się pomiędzy kwartylem pierwszym i trzecim (rozstęp międzykwartylowy). 
Niepokojąca sytuacja związana jest z dziedziczeniem gospodarstwa. Aż 36\% respondentów stwierdziło, że nie posiada następcy. Może to wywierać niekorzystny wpływ na przekazywanie wiedzy, doświadczeń, marki czy kontynuowanie tradycji.
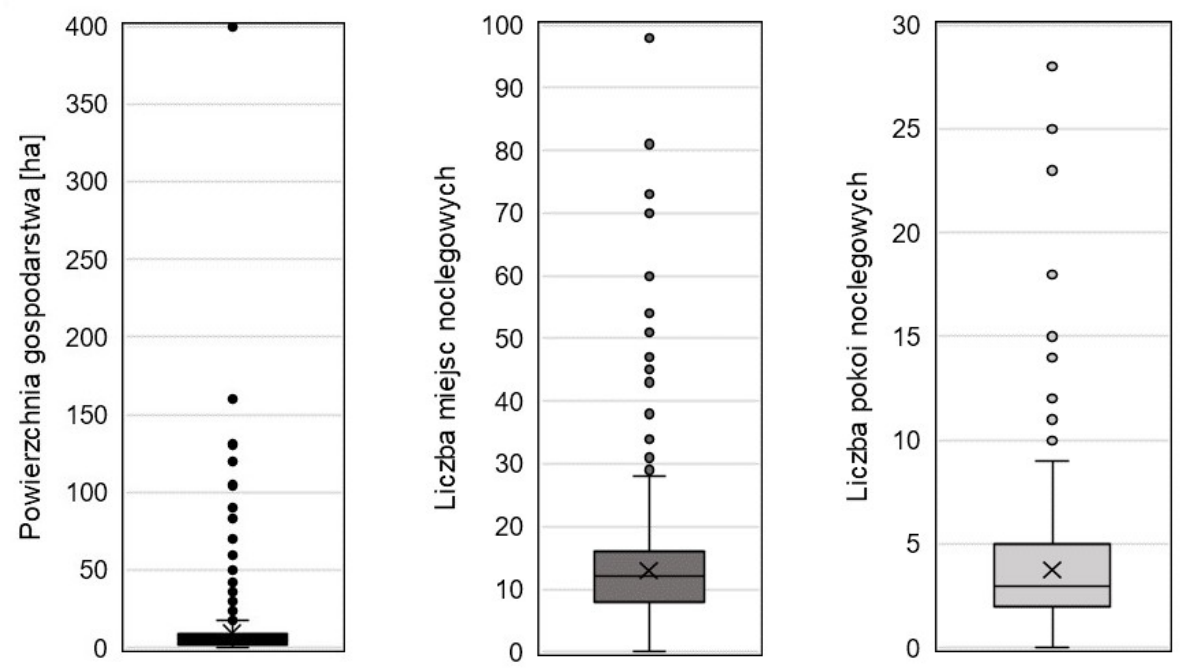

Ryc. 1. Wybrane cechy badanych gospodarstw agroturystycznych

Źródło: opracowanie własne na podstawie wyników badań ankietowych

W kontekście rozważań nad innowacyjnością gospodarstw agroturystycznych za priorytetowy uznać można czynnik przynależności i aktywnej działalności w ramach stowarzyszeń agroturystycznych lub Lokalnych Grup Działania (LGD), za pośrednictwem których może następować przepływ informacji i wiedzy - ważny na rynku w warunkach wysokiej konkurencyjności (Brambert 2016). Aż 56\% ogółu jednostek zadeklarowało współpracę z różnorodnymi stowarzyszeniami (ryc. 2). W południowo-wschodniej części kraju respondenci wskazali podjęcie współpracy aż z 40 różnymi stowarzyszeniami lub LGD. Jednak łącznie ponad $1 / 5$ z nich zrzeszona była $w$ ramach dwóch stowarzyszeń agroturystycznych: „Galicyjskie Gospodarstwa Gościnne” (11\% wskazań) i „Gospodarstwa Gościnne - Zielona Dolina” (10\%) z województwa podkarpackiego.

W działalności agroturystycznej kategoryzacja gospodarstw jest indywidualną sprawą rolnika. Nie ma bezwzględnego obowiązku poddawania się jej. Niemniej jednak ubieganie się o środki pomocowe możliwe jest dopiero po przejściu oceny kategoryzacyjnej Polskiej Federacji Turystyki Wiejskiej (PFTW) „Gospodarstwa Gościnne”. W praktyce przystępują do niej najbardziej aktywne podmioty, które wiążą swoją przyszłość ze świadczeniem usług dla turystów. W badanej zbiorowości jedynie $34 \%$ ogółu obiektów przeszło kategoryzację, w tym 18\% posiada 
kategorię standard (ryc. 3). W dalszym ciągu 66\% gospodarstw pozostaje bez kategorii PFTW. Z punktu widzenia wzrastających wymagań konsumentów nie jest to korzystne, ponieważ coraz więcej turystów wybiera obiekty skategoryzowane, gdyż dzięki temu posiada konkretne informacje oraz może mieć pewność co do jakości oferowanego produktu agroturystycznego.

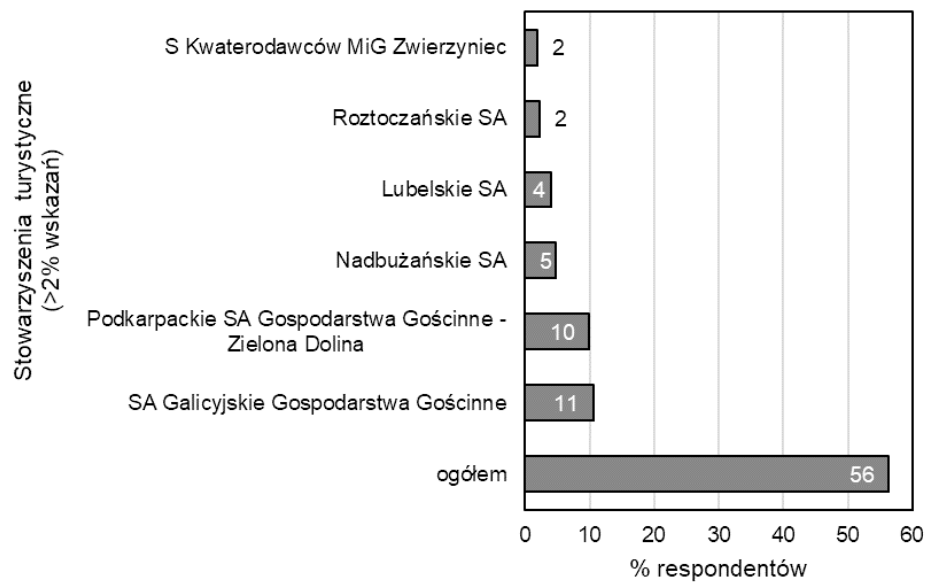

Ryc. 2. Współpraca badanych podmiotów ze stowarzyszeniami turystycznymi Objaśnienia skrótów: S - stowarzyszenie, SA - stowarzyszenie agroturystyczne

Źródło: opracowanie własne na podstawie wyników badań ankietowych

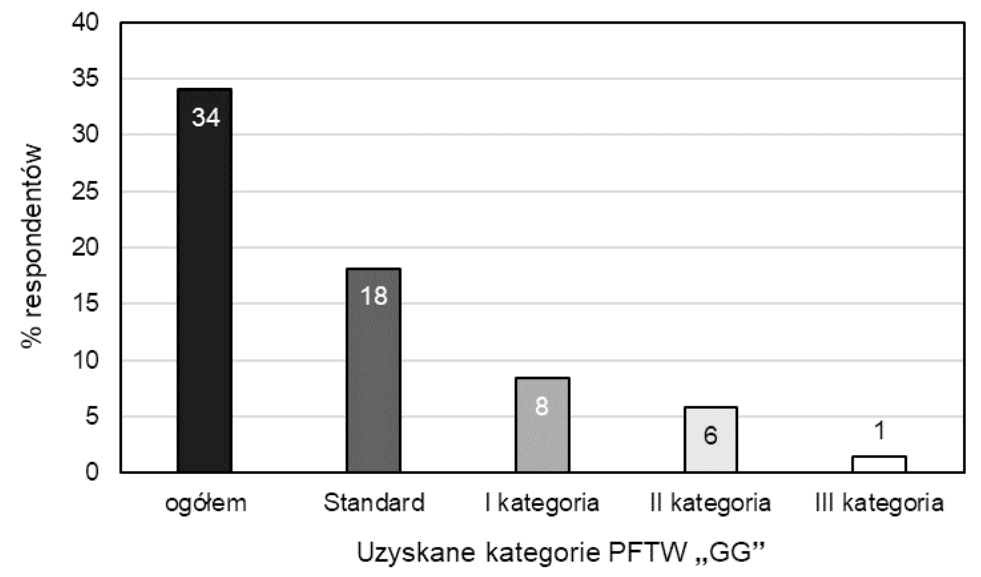

Ryc. 3. Posiadanie przez badane podmioty kategorii Polskiej Federacji Turystyki Wiejskiej „Gospodarstwa Gościnne”

Źródło: opracowanie własne na podstawie wyników badań ankietowych 
Z punktu widzenia innowacyjnych postaw należy dodać, że ankietowani rolnicy - właściciele gospodarstw deklarowali również chęć wdrożenia w najbliższej przyszłości innowacji w prowadzonej działalności. Plany tego dotyczące wyraziło $52 \%$ badanych. Wskazali oni, że chcą w najbliższym czasie rozbudować bazę noclegową (33\%) lub wzbogacić gospodarstwo w nowe wyposażenie (15\%). Tylko w 3\% jednostek rozważa się poszerzenie oferty usługowej (ryc. 4).

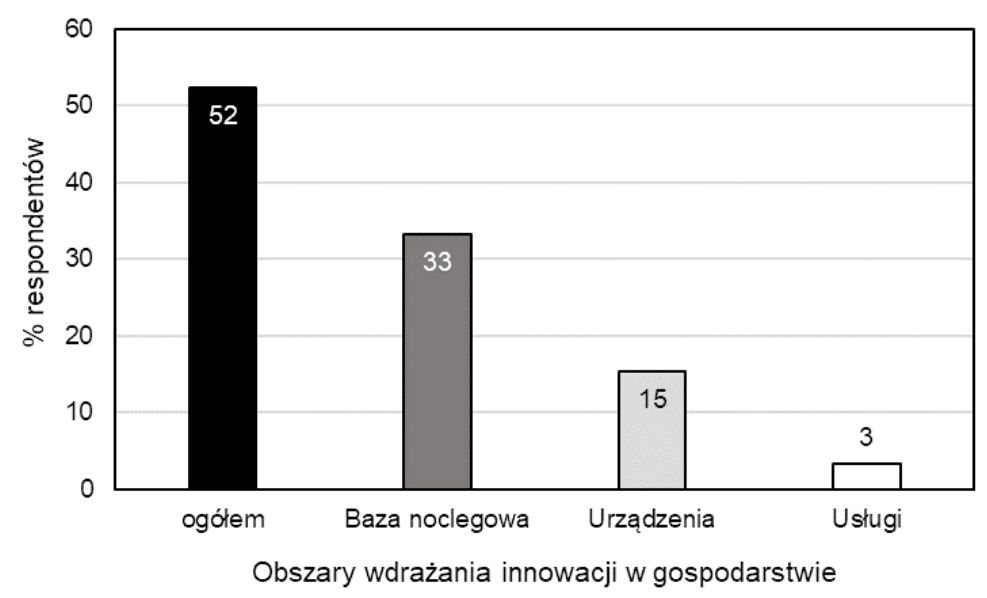

Ryc. 4. Plany wprowadzenia nowych usług lub inwestycji w gospodarstwie agroturystycznym

Źródło: opracowanie własne na podstawie wyników badań ankietowych

Innym nieodłącznym przejawem innowacyjności w agroturystyce jest podejmowanie współpracy z innymi podmiotami. Niezmiernie ważne jest, aby działalność gospodarczą umiejscowić w ramach stosunków społecznych o charakterze sieci, co pozwala na wymianę informacji i wiedzy. Towarzysząca temu rywalizacja stanowić może przykład benchmarkingu ${ }^{2}$, który polega na analizie porównawczej z konkurencją, następnie na naśladownictwie i dokonywaniu ulepszeń. Warto nadmienić, że gospodarstwa agroturystyczne mogą aspirować do funkcjonowania w ramach klastra turystycznego, który jest odmianą sieci współpracy w określonej lokalizacji geograficznej. W jego obrębie bliskie sąsiedztwo przedsiębiorstw i instytucji zapewnia istnienie określonej wspólnoty zwiększając znaczenie oddziaływań, pełniąc rolę stymulatora dla osiągania lepszych rezultatów na rynku (Brambert 2016).

Najlepiej, aby taka współpraca mogła odbywać się na podstawie modelu innowacji, określanym mianem potrójnej helisy. Dotyczy on złożonych interakcji zachodzących w procesie tworzenia wiedzy między trzema sferami: przedsiębior-

${ }^{2}$ Zdaniem B. Plawgo (2014) przedmiot benchmarkingu stanowi konfrontowanie procesów i zasad, wyników, strategii, uwarunkowań. 
stwami (sektor agroturystyczny), sferą badawczo-rozwojową (instytucje wspierające, np. Ośrodki Doradztwa Rolniczego, PFTW) i sferą władz publicznych (jednostki samorządu terytorialnego lokalnego lub regionalnego). Jest to skuteczna droga osiągania efektów synergii na konkurencyjnym rynku, które wynikają z procesów interakcji, powiązań i kooperacji w sieci (Etzkowitz, Leydesdorff 2000; Budner 2013).

Właściciele gospodarstw agroturystycznych w głównej mierze deklarowali współdziałanie ze stowarzyszeniami (40\% przedstawicieli), w drugiej kolejności - z innymi rolnikami (31\%), z urzędami gmin (29\%) oraz ODR-ami (24\%) - (ryc. 5). Współpraca ta w praktyce przybierała różne formy. Gospodarze, będący członkami stowarzyszeń, określili, że ich relacje partnerskie w danym zrzeszeniu polegały zazwyczaj na wymianie doświadczeń (23\% ogółu). W o wiele mniejszym stopniu była to wymiana bazą klientów (9\%) bądź wzajemna reklama (8\%). Relacje w ramach grupy rolników budowane były zarówno na wzajemnej pomocy (17\%), jak i wymianie wiedzy (14\%). Respondenci, którzy mieli możliwość współpracy z administracją samorządową, podejmowali relacje zwłaszcza w sferze działań promujących agroturystykę (20\%). Znikome w tym przypadku były płaszczyzny współdziałania w ramach szkoleń (4\%) i reklamy (3\%). W ramach ODR-ów polegało to głównie na poradach specjalistów (14\%) i szkoleniach $(7 \%)$.

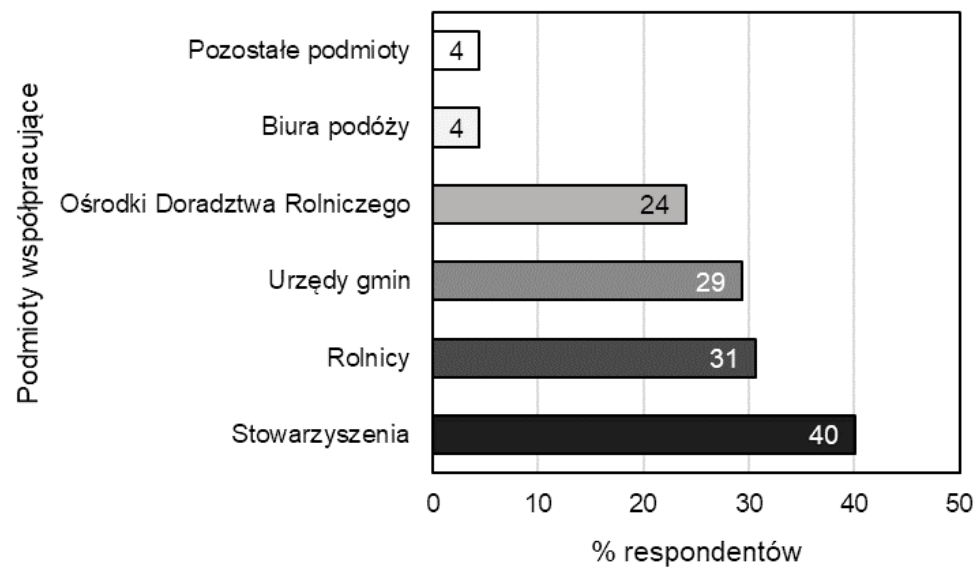

Ryc. 5. Współdziałanie badanych gospodarstw agroturystycznych z innymi podmiotami Źródło: opracowanie własne na podstawie wyników badań ankietowych

W związku z tym, że innowacyjność to m.in. zaangażowanie w zdobywanie zasobów i umiejętności niezbędnych do uczestniczenia w tworzeniu lub pozyskiwaniu różnych rodzajów innowacji (Matusiak 2011), w analizie zwrócono uwage na problem podnoszenia kwalifikacji rolników poprzez uczestnictwo w szkole- 
niach z zakresu turystyki. Na podstawie badań ankietowych stwierdzono, że niemal 70\% osób odpowiedzialnych za działanie gospodarstwa agroturystycznego z Polski południowo-wschodniej uczestniczyło w specjalistycznych szkoleniach. Zajęcia te jako agroturystyczne opisało $19 \%$ odpowiadających, natomiast po $14 \%$ odbyło je w ramach aktywności edukacyjnej stowarzyszeń agroturystycznych i ODR-ów (ryc. 6). Ponadto badani mogli dokonać oceny przydatności takich szkoleń w rozwijaniu agroturystycznej działalności. Zatem w opinii rolników użyteczność i efektywność szkoleń oceniona została generalnie dobrze. Większość oceniła je jako przeciętnie przydatne - 38\%, przy czym znaczny odsetek określił dużą, a następnie bardzo dużą ich przydatność - odpowiednio 29\% i 19\% spośród 607 osób.

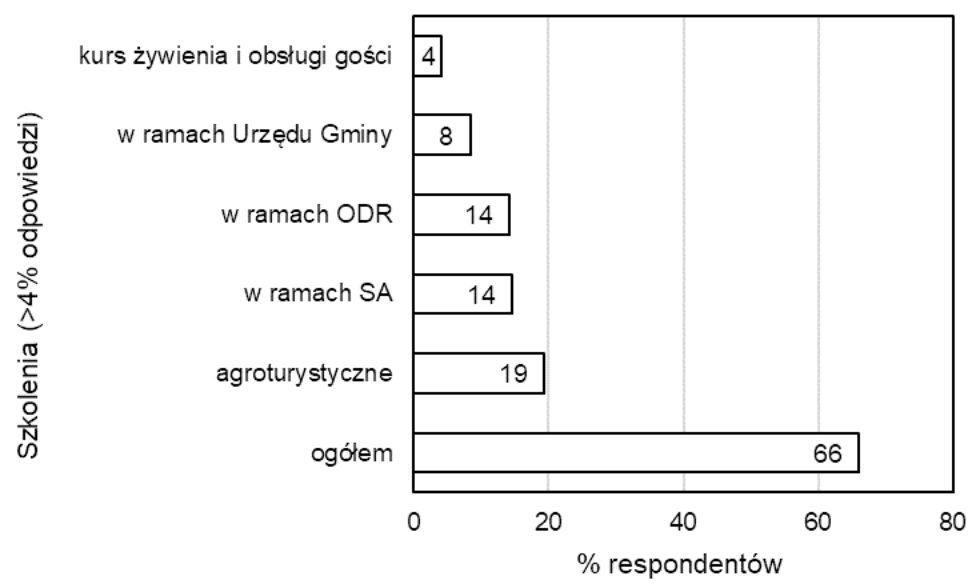

Ryc. 6. Struktura uczestnictwa w szkoleniach z zakresu turystyki

Źródło: opracowanie własne na podstawie wyników badań ankietowych

Znaczącą rolę w przekształceniu społeczno-gospodarczym obszarów wiejskich, w tym - w zmierzaniu do innowacyjności poszczególnych sfer aktywności na wsi - odegrał już 13-letni okres przynależności Polski do Unii Europejskiej (UE). Zapóźnione w rozwoju obszary wiejskie sumarycznie otrzymały ogromne wsparcie finansowe na zlikwidowanie lub zniwelowanie barier, które ograniczały różne aspekty ich funkcjonowania. Dotyczy to oczywiście m.in. turystyki wiejskiej, która wpisuje się w wielofunkcyjny rozwój tych przestrzeni (Kamińska, Heffner 2011). Zatem finansowanie podmiotów sektora turystycznego na obszarach wiejskich ze środków wspólnoty odgrywa obecnie kluczową rolę. Innymi instrumentami wykorzystywanymi w realizacji celów polityki turystycznej są: ulgi i zwolnienia podatkowe, dotacje i subwencje, wydatki budżetowe na inwestycje, promocja turystyczna oraz partnerstwo publiczno-prywatne. 
Dlatego w tym kontekście ocenić należało dodatkowo wpływ przystąpienia do wspólnoty europejskiej na rozwój przedsiębiorstw agroturystycznych w południowo-wschodniej części kraju w świetle opinii respondentów. Zdania na ten temat były podzielone, ponieważ $41 \%$ rolników nie dostrzegło oddziaływania tego czynnika dla posiadanego przedsięwzięcia, a z drugiej strony prawie tyle samo osób (39\%) miało pozytywne odczucia. Brak zdania wyraziło $21 \%$ przedstawicieli. $\mathrm{Na}$ tym tle interesujący jest fakt, że około $3 / 5$ pytanych potwierdziło pozyskanie jakichkolwiek środków pieniężnych pochodzących z programów strukturalnych, zaś mniejsza o 18 punktów procentowych grupa nie wykorzystała tej szansy.

Rozpatrując w tym miejscu rozkład szacunkowych kwot dotacji na rozwój podmiotów agroturystycznych, odnotowano minimalną pulę środków w wysokości 800 zł, zaś maksymalną dochodzącą do 400 tys. zł. Spośród 60\% grupy, która zadeklarowała ich wykorzystanie, połowa oszacowała zakres wsparcia od 9 tys. zł do 28 tys. zł. Mediana kwot była równa 14,5 tys. zł, przy średniej arytmetycznej ok. 24,8 tys. zł. Ilustruje to duże zróżnicowanie wysokości wsparcia wspólnotowego, czy możliwości rozwoju prowadzonej działalności. Należy wspomnieć, że w badaniu ankietowym nie ujęto kierunków inwestowania otrzymanych środków.

Na zakończenie nie można pominąć wskazania, jaki udział w dochodzie gospodarstwa wygenerowała działalność agroturystyczna. Oszacowano go w zakresie od $2 \%$ do $70 \%$, w tym dla $50 \%$ jednostek były to wartości od $9 \%$ do $18 \%$, przy medianie równej $14 \%$ dochodu. W związku z tym, w przypadku zdecydowanej większości przebadanych gospodarstw agroturystyka nie stanowi głównego źródła utrzymania.

\section{Wnioski}

Innowacje są istotnym czynnikiem wpływającym na rozwój gospodarstw agroturystycznych oraz dostosowanie ich do ciągle wzrastających wymagań rynku. Równocześnie implementowanie innowacji do gospodarstw skutkuje zwiększaniem ich konkurencyjności. Pozwala także zaspokoić potrzeby właściwych segmentów rynku. Nie należy zapominać, aby przy tym nie utracić tradycyjnych walorów obszarów wiejskich, np. specyficznego krajobrazu, niezdegradowanego środowiska przyrodniczego i dziedzictwa kulturowego. Są one dla przeciętnego turysty unikalnym przejawem także innowacyjności polskiej wsi.

Na podstawie analizy wyników przeprowadzonych badań ankietowych sformułowano następujące wnioski:

1. Wzrost dochodów oraz wymogi gospodarki rynkowej stymulują innowacyjność podmiotów agroturystycznych.

2. Usługodawcy w agroturystyce najwięcej uwagi przypisują innowacjom produktowym, pomimo że ich wprowadzanie nie jest procesem łatwym. Każde 
wdrożenie produktu wiąże się z ponoszeniem nakładów finansowych oraz stwarza niepewność, czy podjęta decyzja przyniesie oczekiwany zysk.

3. Można przypuszczać, że deklarowana przez prawie połowę respondentów niechęć do innowacyjności wynika często z braku wiedzy w tym zakresie.

4. Większość właścicieli podmiotów agroturystycznych, poprzez otwartość na współpracę z różnymi instytucjami, przejawia świadomość istotnej roli współdziałania i dyfuzji wiedzy w rozwoju innowacyjności.

5. Przejawy współpracy gospodarstw miały zróżnicowany charakter. W odniesieniu do stowarzyszeń największą rolę odgrywa wymiana doświadczeń, w przypadku samych rolników - wzajemna pomoc w agroturystyce, urzędy gminy pomagały im w promocji, zaś ODR-y oferowały wsparcie specjalistów.

6. Niejednoznaczna ocena wpływu przystąpienia Polski do UE pod kątem rozwoju posiadanych gospodarstw agroturystycznych może świadczyć, że badana społeczność wiejska nie odczuwa w sposób wyraźny pozytywnych efektów akcesji.

\section{Literatura}

Alejziak B., 2009, Innowacyjna gospodarka a turystyka, [w:] Feczko J. (red.), Rozwój turystyki w warunkach Unii Europejskiej, Wyższa Szkoła Ekonomii i Prawa im. prof. Edwarda Lipińskiego, Kielce: 25-39.

Bednarska M., Gołembski G., Markiewicz E., Olszewski M., 2007, Przedsiębiorstwo turystyczne. Ujęcie statyczne i dynamiczne, Polskie Wydawnictwo Ekonomiczne, Warszawa.

Brambert P., 2016, Wplyw wspótpracy sieciowej na przedsiębiorczość i innowacyjność w regionie świętokrzyskim na przykładzie klastra Grono Targowe Kielce, Praca doktorska, Uniwersytet Jana Kochanowskiego w Kielcach.

Budner W., 2013, Klastry w gospodarce lokalnej - znaczenie, czynniki i bariery rozwoju, [w:] Fimińska-Banaszyk R., Zimny A. (red.), Doskonalenie zarzadzania w samorzadach lokalnych, Wydawnictwo Państwowej Wyższej Szkoły Zawodowej w Koninie, Konin: 9-20.

Dębniewska M., Wojtowicz K., 2014, Innowacyjność i konkurencyjność w zarzadzaniu matym przedsiębiorstwem turystycznym, [w:] Snarski S., Jalinik M. (red.), Przedsiębiorczość w turystyce, Wydawnictwo EkoPress, Białystok.

Drucker P.F., 1992, Innowacje i przedsiębiorczość. Praktyka i zasady, Państwowe Wydawnictwo Ekonomiczne, Warszawa.

Etzkowitz H., Leydesdorff L., 2000, The dynamics of innovation: From national systems and ,Mode 2" to a triple helix of university-industry-government relations, „Research Policy", 29(2): 109-123.

Gancarczyk J., 2012, Innowacje w matych $i$ średnich przedsiębiorstwach turystycznych, „Zeszyty Naukowe Uniwersytetu Szczecińskiego. Ekonomiczne Problemy Usług”, 91: 105-123. 
Janasz W. (red.), 2004, Innowacje w rozwoju przedsiębiorczości w procesie transformacji, Wydawnictwo Difin, Warszawa.

Janasz W., 2005, Innowacje $i$ ich miejsce $w$ tworzeniu wartości przedsiębiorstwa, [w:] Janasz W. (red.), Innowacje $w$ działalności przedsiębiorstw $w$ integracji z Unia Europejska, Wydawnictwo Difin, Warszawa: 23-63.

Kamińska W., Heffner K. (red.), 2011, Obszary wiejskie: wielofunkcyjność, migracje, nowe wizje rozwoju, „Studia KPZK PAN”, 133, Warszawa.

Lichniak I., 2010, Cechy podmiotu innowacyjnego. Region innowacyjny, [w:] Godlewska-Majkowska H. (red.), Innowacyjność jako czynnik wzrostu atrakcyjności inwestycyjnej polskich regionów w latach 2002-2007, Wydawnictwo SGH, Warszawa: 14-16.

Lumpkin G.T., Dess G.G., 2001, Linking two dimensions of entrepreneurial orientation to firm performance: The moderating role of environment and industry lifecycle, „Journal of Business Venturing", 5: 429-451.

Matusiak K.B. (red.), 2011, Innowacje i transfer technologii. Słownik pojęć, PARP, Warszawa.

Niedzielski P., Markiewicz J., Rychlik K., Rzewuski T., 2007, Innowacyjność w dziatalności przedsiębiorstw. Kompendium wiedzy, Wydawnictwo Naukowe Uniwersytetu Szczecińskiego, Szczecin.

Pałka E., 2015, Innowacje $w$ gospodarstwach agroturystycznych Polski poludniowo-wschodniej, „Studia i Materiały. Miscellanea Oeconomicae”, 4: 73-88.

Panasiuk A., 2014, Procesy innowacyjne $w$ ksztattowaniu struktury rynku turystycznego, [w:] Snarski S., Jalinik M. (red.), Przedsiębiorczość w turystyce, Wydawnictwo Eko-Press, Białystok.

Plawgo B. (red.), 2014, Benchmarking klastrów w Polsce-edycja 2014. Raport ogólny, Polska Agencja Rozwoju Przedsiębiorczości, Warszawa.

Puciato D., Woś B., 2011, Innowacje jako forma wzbogacenia oferty wybranych gospodarstw agroturystycznych w Górach Świętokrzyskich, „Folia Pomeranae Universitatis Technologiae Stetinensis. Seria Oeconomica”, 64: 113-124.

Schumpeter J.A., 1939, Business cycles: a theoretical, historical and statistical analysis of the capitalist process, McGraw-Hill Book Company, New York-Toronto-London.

Schumpeter J.A., 1960, Teoria rozwoju gospodarczego, Państwowe Wydawnictwo Naukowe, Warszawa.

Szymańska E., 2013, Procesy innowacyjne przedsiębiorstw świadczacych ustugi w zakresie organizacji imprez turystycznych, Oficyna Wydawnicza Politechniki Białostockiej, Białystok.

Wyszkowska Z., 2012, Uwarunkowania rozwoju przedsiębiorczości na obszarach wiejskich, ,Journal of Agribusiness and Rural Development”, 3: 299-307.

\section{INNOVATIVENESS IN AGRITOURIST FARMS}

Abstract: Agritouristic space in the southeastern Poland is determined by many factors of a different nature. Actually innovations in agritourism are recognized as more and more important factors. They are desirable in order to achieve competitiveness of touristic offers on rural areas. This paper concerns identification of innovations introduced by agritourist 
farms situated in four voivodeships of mentioned part of the country: Lubelskie, Małopolskie, Podkarpackie and Świętokrzyskie. The main goal was to assess the innovativeness of determined undertakings. It was built on the analysis of some opinions about these problems of a selected group of 607 holders of agritourist farms. The survey was held in 2016.

Keywords: rural areas, innovations, agritourism, innovativeness, agritourist farm.

Dr Ewa Pałka-Łebek

Zakład Geografii Społeczno-Gospodarczej

Instytut Geografii

Wydział Matematyczno-Przyrodniczy

Uniwersytet Jana Kochanowskiego w Kielcach

e-mail: ewa.palka@ujk.edu.pl

Dr Patryk Brambert

Zakład Badań Regionalnych i Gospodarki Przestrzennej

Instytut Geografii

Wydział Matematyczno-Przyrodniczy

Uniwersytet Jana Kochanowskiego w Kielcach

e-mail: patryk.brambert@ujk.edu.pl 